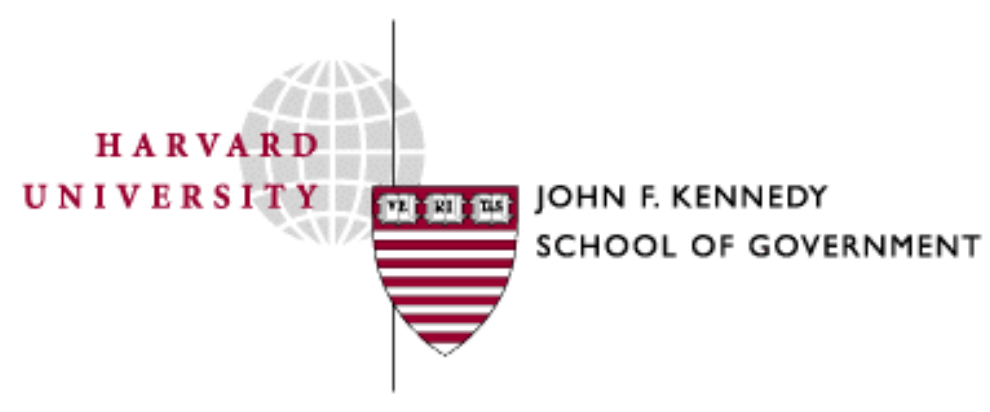

Faculty Research Working Papers Series

\title{
Who Has Benefited from Economic Growth in the United States since 1969? The Case of Children
}

\author{
Christopher Jencks, Susan Mayer and Joseph Swingle
}

March 2004

RWP04-017 belongs to the author(s). Papers may be downloaded for personal use only. 


\title{
Who Has Benefited from Economic Growth in the United States since 1969? The Case of Children
}

\author{
Christopher Jencks \\ John F. Kennedy School of Government \\ Harvard University \\ Susan E. Mayer \\ Irving B. Harris Graduate School of Public Policy Studies \\ University of Chicago \\ and \\ Joseph Swingle \\ Wellesley College \\ To appear in \\ Edward Wolff, editor, What Has Happened to the Quality of Life in the Advanced \\ Industrialized Nations? Edward Elgar, forthcoming.
}

March 22, 2004

DO NOT CITE WITHOUT THE AUTHORS' PERMISSION

This paper was prepared with the support of the Jerome Levy Institute and the American Academy of Art and Science's Initiative on Children. It was completed while Jencks was a Hewlett Fellow at the Center for Advanced Study in the Behavioral Sciences. David Knutson, Judith Levine, Ankur Sarin, Timothy Veenstra, and Scott Winship provided valuable research assistance. 


\section{WHO HAS BENEFITED FROM ECONOMIC GROWTH \\ IN THE UNITED STATES SINCE 1969? \\ THE CASE OF CHILDREN}

Affluent Americans remember the 1990s as a period of remarkable prosperity, during which the stock market soared and unemployment fell to its lowest level in thirty years. Real per capita Gross Domestic Product (GDP) rose 19 percent. ${ }^{1}$ Although this cheery picture is widely accepted, household surveys tell a less encouraging story. According to the Census Bureau’s Current Population Survey (CPS), households' mean pretax money income rose only 11 percent between 1989 and 1999, and because most of this increase went to the top half of the distribution, the median household's real money income rose only 5.1 percent (US Bureau of the Census, 2000a, Table B-2). Discrepancies of this kind have led to a long-running war of words between optimists who see America's economic system as a model for the rest of the world and pessimists who see American experience as proof that laissez faire capitalism benefits the few at the expense of the many.

Those who want to demonstrate the harmful effects of slow growth and rising inequality tend to concentrate on trends among children. Figure 1 displays what we will call the pessimistic picture of income trends among American children over the past generation. The data come from the CPS and show the percentage change in real household income for children at the tenth, fiftieth, and ninetieth percentiles of the distribution. ${ }^{2}$ We concentrate on 1969, 1979, 1989, and 1999. These years have the advantage of falling at or near business cycle peaks. Using them also allows us to write

\footnotetext{
${ }^{1}$ For statistics on per capita GDP see Council of Economic Advisers (2002), Table B-31.

${ }^{2}$ Because of the spread of cohabitation, all our analyses treat households rather than families as the unit of analysis. We weight each household by the number of children under eighteen living in it. This means that our results are representative of children, not parents. Suppose, for example, that we observe two couples, one of which has one child and one of which has three children. The average parent in this sample has two children. But the average child lives in a household that includes $[(1)(1)+(3)(3)] / 4=2.5$ children. Figure 1 shows household incomes at the 10th, 50th, and 90th percentiles because changes in the top coding of income from different sources introduce some error into comparisons at the very top of the distribution. Appendix Table A. 2 shows mean household income by quintile.
} 
about trends in successive decades, keeping our prose a little simpler than it otherwise would be.

Figure 1 tells a grim story, especially for the 1970s and 1980s. Although highincome children experienced significant gains between 1969 and 1989, middle-income children gained nothing during these years and low-income children lost more than highincome children gained, at least in percentage terms. Furthermore, while real income rose throughout the distribution during the 1990s, low-income children were still much worse off in 1999 than they had been in 1969. Indeed, even middle-income children were only 8 percent better off in 1999 than in 1969. Figure 1 does not suggest that American capitalism has been distributing the benefits of economic growth very widely.

Figure 2 is based on the same CPS data as Figure 1, but it changes the measure of children's economic status in two ways. First, it takes account of the fact that households got smaller between 1969 and 1999. To do this we replace total household income with per capita household income. Second, it replaces the Consumer Price Index for Urban Consumers (CPI-U), which the Census Bureau has traditionally used to adjust incomes for inflation, with a revised index known as the CPI-U-RS, which corrects a number of well-documented problems in the way the Bureau of Labor Statistics (BLS) used to calculate CPI-U. These problems had all been corrected by 1999 . But because government benefits, tax brackets, and even private pay scales are often tied to the CPIU, BLS never changes it retroactively. The CPI-U-RS seeks to approximate what the CPI-U would have done if BLS had adopted its current methods earlier.

In one crucial respect Figures 1 and 2 tell a consistent story. High-income children always gain the most, and inequality always rises. In other respects, however, Figure 2 dramatically alters our picture of children's economic progress since 1969. Instead of being 24 percent poorer in 1999 than in 1969, low-income children are now 14 percent richer. Middle-income children's real household income now rises by 45 rather than 8 percent. In Figure 1 growing inequality means that the rich grew richer while the poor grew poorer. In Figure 2 growing inequality means that everyone grew richer but that the rich gained more than the poor. Confronted with Figure 1, many Americans would probably say that "this is unfair" or perhaps even that "something should be done." Confronted with Figure 2, these skeptics might become more cautious, saying that "if 
growing inequality is the price we have to pay for making everyone better off, so be it.”

But it is far from clear that Figure 2 tells a more accurate picture than Figure 1. First, no price index is perfect. The CPI-U-RS may be better than the CPI-U, but not everyone who studies such matters agrees that this is the case. Second, although household size changed and everyone agrees that smaller families need less money than large families, there is no agreement about how much less money smaller families need. In addition households' noncash income changed dramatically from 1969 to 1999, and figure 2 ignores this change.

This paper tries to adjudicate between Figures 1 and 2. The first section looks more carefully at the data on income, household size, and prices. We end up preferring Figure 2 to Figure 1, but we also conclude that theoretical arguments alone cannot resolve the controversy. Choosing between these two pictures ultimately requires us to look at direct measures of changes in children's material well-being. Section 2 therefore examines trends in children's housing conditions, access to automobiles, telephone service, physician visits, and food consumption. Most of these measures show trends more like those in Figure 2 than Figure 1.

\section{Measuring changes in household income and consumption.}

Most people are interested in the way family income has changed over time because they expect income statistics to tell them something about changes in the material standard of living. When "real” income goes up, we expect living conditions to improve. When real income goes down, we expect living standards to deteriorate. Figure 1 is alarming because it implies that low-income children experienced substantially more material hardship in 1999 than in 1969. But anyone who uses changes in household income as a guide to changes in material well-being must solve at least four problems: how to adjust for price changes, how to adjust for changes in household size, how to adjust for changes in noncash income, and how to adjust for changes in the ratio of consumption to income.

Price changes. When inflation began to accelerate in the 1970s, economists began to pay more attention to the way in which BLS calculated the CPI-U. As time went on, a growing number concluded that the CPI-U overstated the "true" rate of price 
change. ${ }^{3}$ In response to these criticisms -- some of which came from its own economists -- BLS made numerous changes in the way it calculated the CPI-U.

The single most important change involved owner-occupied housing. A home is both a place to live and an investment. The CPI-U is supposed to track changes in the price of shelter, not changes in the value of people's real estate investments. But until 1983 BLS estimated the cost of owner-occupied housing by tracking sale prices and mortgage interest rates. Both sale prices and interest rates soar when investors think that inflation is likely to continue. But for those who already own a home, increases in sale prices represent windfall profits, and increases in interest rates on new mortgages are irrelevant. If one wants to track the current cost of shelter, sale prices and interest rates are likely to be quite misleading. What one needs are data on the cost of renting different kinds of residences. In 1983 BLS began using current rents to estimate the cost of all housing, including units occupied by their owner. BLS also produced a price index, known as the CPI-U-X1, which estimated how much the CPI-U would have changed if BLS had begun using rent levels in 1967.

In more recent years BLS has made a number of other changes in the way it calculates the CPI-U. Most of these changes have lowered the estimated rate of inflation. The CPI-U-RS estimates what would have happened to the CPI-U if all these changes had been introduced in 1977. ${ }^{4}$ The Census Bureau has extended the CPI-U-RS back to 1967 by splicing it to the CPI-U-X1. Table 1 shows that this version of the CPI-U-RS, which is also the one we use, rises considerably less rapidly than the CPI-U. The disparity averages about 0.43 percentage points a year. For the period between 1969 and 1999, the CPI-U rises 13 percent more than the CPI-U-RS. As a result, incomes adjusted for inflation with the CPI-U-RS rise 13 percent more than incomes adjusted with the CPIU.

Unfortunately, even the CPI-U-RS is likely to overstate inflation since 1969. To begin with, the CPI-U-RS does not tell us how the CPI-U would have changed between 1969 and 1977 if BLS had been using today’s procedures. Since these changes reduced

\footnotetext{
${ }^{3}$ For a strong statement of this argument see Boskin et al (1996). For a good introduction to the Consumer Price Index and its critics see Schultz and Mackie (2002).

${ }^{4}$ Stewart and Reed (1999) describe the CPI-U-RS in more detail.
} 
the estimated rate of inflation between 1977 and 1999, they probably would have done the same thing between 1969 and 1977. In addition, BLS has traditionally estimated price changes by tracking the cost of a market basket that remains fixed for roughly a decade. Because consumers shift their purchasing patterns in response to changes in relative prices, using an outdated market basket tends to exaggerate the amount of income consumers need to buy a market basket they regard as equivalent to the one they used to buy. The Commerce Department's Bureau of Economic Research, which produces the National Income and Product Accounts (NIPA), deals with this problem by constructing a "chain-price" index, in which the market basket for what it calls Personal Consumption Expenditure (PCE) changes every year.

If the PCE market basket included only goods and services that consumers paid for out of their own pockets, we might want to adopt it for estimating changes in real household income. But the PCE market basket also includes some goods and services that consumers do not pay for out of their own income, the most important of which is the portion of medical care financed by Medicare, Medicaid, and employers' share of their workers' health insurance. One way to make the CPI-U-RS and the PCE chain-price index more comparable is to exclude medical services from both indexes. ${ }^{5}$ The bottom panel of Table 1 when we do this for the 1990s the annual increase in the chain-price index for non-medical consumption was about 0.3 points less than that in the non-medical CPI-U and 0.6 points less than that in the non-medical CPI-U-RS.

Technical innovation may also cause all these price indexes to rise faster than they should. In 1984, for example, the cost of treating a heart attack averaged \$11,175 (in 1991 dollars). By 1991 the average cost had risen to $\$ 14,772$. BLS treats this change as a price increase. But heart attack victims lived an average of 70 months in 1991, compared to 62 months in 1984 (Cutler et al, 1998). Most experts attribute this increase to technical progress. Each extra month of life expectancy thus cost about $(\$ 14,772-$ $11,175) / 8=\$ 450$. Most patients and their families would presumably have thought this an acceptable price. If so, the increased cost of treatment was not a true price increase.

\footnotetext{
${ }^{5}$ Even after excluding medical services the PCE and CPI market baskets are not exactly comparable, but as far as we know the remaining differences are unlikely to have a major impact on estimated price trends.
} 
Instead, it was analogous to the increased cost of "motor vehicles" that occurs when people start buying tinted windows or switch from Toyotas to BMWs.

We have no way of knowing whether Cutler et al's findings would recur if we studied a random sample of medical price changes. The key point is that some part of the increase in the CPI-U-RS is probably attributable to improvements in the quality of goods and services. In other cases, of course, quality has deteriorated. Computerized menus for answering telephone calls are an obvious and irritating example. Declines in quality are probably less common than improvements, but it is hard to be sure.

Noncash benefits. Means-tested noncash government benefits increased rapidly between 1965 and 1980, but the Census Bureau did not begin collecting data on such benefits until 1979. Since 1979 the March CPS has included questions about noncash income (including owner-occupied housing), and the Census Bureau has tried to estimate their cash value to recipients. The Bureau assigns Food Stamps their face value. It values housing subsidies by estimating the difference between a subsidized unit's market value and what tenants actually pay. It values Medicare and Medicaid by estimating how much they reduce beneficiaries’ out-of-pocket medical spending. The Bureau’s approach to medical benefits is especially controversial. It approximates the increase in recipients' nonmedical standard of living, but it assigns no value to the extra medical services that beneficiaries consume when they are covered. ${ }^{6}$

Table 2 compares trends in after-tax money and nonmoney income to trends in pretax money income. Taxes and noncash benefits make the distribution of resources per capita look far more equal. One simple measure of inequality is the ratio of mean income in the top quintile to mean income in the bottom quintile. Shifting from pretax money income to after-tax money and nonmoney income lowered this ratio by more than a third in 1999. But taking account of taxes and noncash benefits has a quite modest effect on post-1979 trends. After-tax money and non-money incomes rose a little faster (or fell a little less) than pre-tax money income for all groups. This was especially true for low-

\footnotetext{
${ }^{6}$ In the early 1980s the Census Bureau estimated the market value of an insurance policy that provided coverage equivalent to state Medicaid programs. In some states, however, Medicaid was worth so much to the elderly that they could end up with an imputed income above the poverty line even if they had no cash income, no food stamps, and no housing subsidy, so this method was dropped.
} 
income children, whose after-tax money and nonmoney income rose about 6 percent more than its pretax money income. ${ }^{7}$

We have no data on after-tax money and nonmoney income in 1969, but we know that the number of families receiving noncash benefits grew faster in the 1970s than in either the 1980s or the 1990s. Food Stamps became a national program in 1972, and real program outlays per capita were fourteen times higher in 1979 than in 1969. The percentage of low-income children in federally subsidized housing roughly doubled, and the value of the subsidy to the average tenant also rose. ${ }^{8}$ Real per capita Medicaid outlays rose by a factor of 2.5 during these years. The Census Bureau's estimates suggest that these three programs raised low-income children's pretax household income by about a sixth in 1979. Our best guess is that they raised pretax money income by only three percent in 1969. ${ }^{9}$ We do not know how the distribution of taxes and other benefits changed during these years, but if they remained unchanged, low-income children's real incomes would have risen by about 14 percent between 1969 and 1979 rather than by 2 percent, as Figure 2 indicates.

Changes in household size. In 1969 the average child's household included 2.2 adults and 2.3 other children under eighteen. By 1999 the average child's household included only 2.1 adults and 1.4 other children. The total number of people in children's households therefore fell by 18 percent (from 5.5 to 4.5 individuals). Most of this change occurred during the 1970s. Figure 1 ignored this change. Figure 2 assumed that an 18 percent reduction in household size implied an 18 percent reduction in the household's economic needs. This adjustment is likely to overstate the material benefits of reducing household size, because it ignores economies of scale. A household composed of four does not need twice as many kitchens as a household of two. Nor does the household of four need twice as many automobiles or clothes dryers as the household of two.

\footnotetext{
${ }^{7}$ Appendix Table A-1 shows that the ratio of after-tax money and nonmoney income to pretax money income is essentially the same for total and per capita income. When we calculate trends in per capita household income by quintile we allocate households to quintiles based on their per capita income rather than their total income.

${ }^{8}$ Jencks, Mayer, and Swingle (2002) estimate that the fraction of low-income families receiving some kind of rent subsidy rose from 6.0 percent in 1969 to 13.5 percent in 1979.

${ }^{9}$ This guess assumes that the value of benefits to the bottom quintile of households with children grew at the same rate as real per capita government outlays on the programs.
} 
Economists have devised various "equivalence scales" that seek to determine how much money households of different sizes need to be equally well off. ${ }^{10}$ It is easy to determine the amount of income that makes a family of four comparable to a family of two in some specific respect, such as the size of its TV set. But an equivalence scale that equalizes families one measure of well-being is not especially likely to equalize them on other measures. If we want to construct an overall equivalence scale we need some more general criterion for comparing families of different sizes. Economists sometimes solve this problem by assuming that families of different sizes have the same tastes and then asking what income level generates similar expenditure patterns. But people often live in households of different sizes because their tastes differ. People have children, for example, because they would rather spend their income on eating at home with their children than on taking the spouse to a restaurant. People who value restaurants highly are likely to have smaller families than those who do not, so we cannot assume that families of different sizes are equally well off when they spend the same fraction of their food budget on restaurant meals.

If our goal is to predict adults' well-being, adjusting for how many children they have makes no more sense than adjusting for how many cars they have. Both children and cars are expensive, and both leave adults with less money for everything else. But we would not want to conclude that a couple with a income of $\$ 40,000$ was poorer if they had two cars than if they had one, and neither should we conclude that they are poorer when they have two children rather than one.

If our goal is to predict children's well-being, however, the problem is quite different. Children do not choose to have additional siblings, and there is no evidence that children benefit from having additional siblings. Additional siblings reduce both a child's material standard of living and the amount of time and attention the child is likely to get from his or her parents. For a child, therefore, per capita household income may be more relevant than total household income. In the absence of solid evidence, however, the best strategy is to track trends in both total and per capita household income and use the two measures to place upper and lower bounds on changes in economic well-being.

${ }^{10}$ For a good general review of the large literature on equivalence scales see Michael and Citro (1995). 
Consumption versus income. The Census Bureau's measure of pretax money income can also provide a misleading picture of changes in the material standard of living if the ratio of personal consumption to income is changing. This can happen when the government finances a growing fraction of personal consumption through noncash benefits like Medicare and Medicaid. It can also happen when tax rates, saving rates, or interest rates change. ${ }^{11}$ Table 3 compares NIPA estimates of total personal consumption in the nation as a whole to Census Bureau estimates of total pretax money income in the nation as a whole. This ratio has risen steadily since $1969 .^{12}$

Conclusions about income and consumption. None of the problems discussed in this section has a definitive solution. There is no general agreement about how one should adjust income for changes in prices, changes in household size, or changes in noncash benefits. Conclusions about changes in households' material living standard therefore need to be tested against other sources of evidence. The next section uses data on changes in the material standard of living to see whether Figure 1 or Figure 2 tells a more accurate story about changes in children's economic resources over the past generation.

\section{Trends in Children's Living Conditions}

If low-income children's real incomes declined between 1969 and 1989, as Figure 1 implies, children should have experienced more material hardship and should have had less access to luxuries of various kinds in 1989 than in 1969. If low-income children's real incomes were relatively flat between 1969 and 1989, as Figure 2 suggests, we should not see much change in material hardship or in the availability of luxuries. Likewise, if children's incomes rose faster in the middle of the distribution than at the bottom, as both Figures 1 and 2 suggest, living conditions should have improved more among middleincome than low-income children.

\footnotetext{
${ }^{11}$ Both NIPA and BLS exclude taxes and interest payments from "personal consumption."

${ }^{12}$ We also investigate the ratio of reported consumption to reported income in the Consumer Expenditure Survey, but after many years of working with these data we concluded that neither the income data nor the consumption data were of high enough quality to be useful for our purposes.
} 
To investigate these questions we look at changes in housing conditions, automobile ownership, air conditioning, telephone service, physician visits, and food consumption. We did not select these items because they seemed ideal from some theoretical perspective. We selected them because the federal government had collected data on these items at the household level since the late 1960s or early 1970s. Federal agencies tend to be more interested in the distribution of what the public regards as necessities than in the distribution of what the public regards as luxuries. As a result, the government seldom starts collecting data on the availability of a good or service until most affluent families already have it. For this reason we focus on trends among low and middle-income children, ignoring high-income children.

We report the percentage of children in the top, middle, and bottom income quintiles whose household has a given problem or amenity. Appendix Table A-1 shows changes in mean income for each of these three groups. The trends are very close to those shown in Figures 1 and 2, except that the mean of the top quintile rises even more than the 90th percentile, because the biggest gains were at the very top. The official child poverty rate, which is based on the CPI-U, was 14.0 percent in 1969, 16.4 percent in 1979, 19.6 percent in 1989, and 16.9 percent in 1999 (US Bureau of the Census, 2000b, Table B-2), so most children in the bottom quintile are officially poor in all periods.

Our initial analyses of living standards classified children by both per capita income and total household income. Roughly half of our measures were more strongly correlated with total income than with per capita income, while the opposite was true for the other half. Because trends were very similar regardless of which measure we used, we present only the results based on total household income, which is more familiar.

To facilitate comparisons between changes in living conditions and changes in income, we report changes in living conditions for two separate periods. The first period starts in either 1969 or 1973 and runs through 1989. All our income data suggest that low-income children either lost ground or made no gains during these years. (Children's real income appears to be fairly flat between 1969 and 1973, so trends between 1973 and 1979 are quite similar to those between 1969 and $1979 .{ }^{13}$ ) Our second period starts in

\footnotetext{
${ }^{13}$ The official child poverty rate rises by 2.4 points between 1969 and 1979 . Five-sixths of this increase (2.0 points) occurs after 1973 (US Bureau of the Census, 2000b, Table B-2).
} 
1989 and runs through the late 1990s. Our income data suggest that children at all income levels made gains during these years.

Housing Conditions. We examine four attributes of children's housing: the overall character and ownership of the housing unit, whether the unit was crowded, whether it had various kinds of physical deficiencies, and whether it was located in a dangerous neighborhood. Our data come from the American Housing Survey (AHS), which began in 1973 .

Type of housing and ownership. The fraction of low-income children living in rural areas and small towns declined during the 1970s and 1980s, while the fraction living in the more densely populated central cities of metropolitan areas grew. As a result, low-income children were more likely to live in apartment buildings and less likely to live in single-family homes. The fraction of low-income children living in multi-family buildings rose from 26.6 percent in 1973 to 38.1 percent in 1979 and then more or less leveled off (see Table 4). There was no clear trend in the proportion of middle-income children living in multi-family units. Not surprisingly, the shift into apartment buildings was accompanied by a decline in home ownership (see Table 4). Home ownership also declined among more affluent parents during the 1980s, perhaps because real interest rates were unusually high. ${ }^{14}$ During the 1990s parents at all income levels began buying homes again.

Crowding. Because of the shift to central cities, low-income children's homes had slightly fewer rooms in 1979 and 1989 than in 1973. But the number of people living in low-income children's households fell even faster than the number of rooms, so the proportion of low-income children in what the Census Bureau calls crowded conditions (more than one person per room) dropped sharply (see Table 5).

Neither mean household size nor the mean number of rooms changed much during the 1980s, so crowding did not change much either. ${ }^{15}$ During the 1990s, in

\footnotetext{
${ }^{14}$ In the 1970 decennial census 60.6 percent of low-income children lived in rented housing. This rose to 63.1 percent in 1980 . This increase was considerably smaller than the increase observed in AHS data. In the 1990 decennial census 71.9 percent of low-income children lived in rented housing, so the increase over this decade is similar in the AHS and Census.

${ }^{15}$ The decennial census also asks about household size and number of rooms. In 197041.7 percent of low-income children lived in a home with more than one person per room. This dropped to 26.8 percent in 1980 then to 27.0 percent in 1990 . Thus there appears to have been a
} 
contrast, children's households got smaller at all income levels while their homes got larger. While many critics of the 1996 welfare reform legislation feared that it would force more single mothers to "double up," Table 4 suggests that crowding declined even among children in the poorest quintile.

Housing problems. We used the AHS to examine seven housing problems: holes in the floor, cracks or holes in walls or ceilings, a leaky roof, broken plaster or peeling paint in an area of more than one square foot, not having a sewer or septic system, not having electric outlets in every room, and not having complete plumbing. Complete plumbing means having hot and cold running water, a sink, a toilet, and a shower or tub. Plumbing must be indoors and for the exclusive use of household members to count, but until the 1980s it could be down the hall rather than inside an apartment.

Table 6 shows that the mean number of problems in low-income children's homes declined steadily between 1973 and 1999. The decline between 1973 and 1989 was somewhat larger than the decline between 1989 and 1999 in both absolute and percentage terms. This pattern holds for most specific problems as well (see Appendix Table A-2). Declines during the 1970s and 1980s suggest that even Figure 2 may underestimate the improvement in low-income children's material standard of living during these years.

Disparities in the number of problems experienced by low and middle-income children also narrowed between 1973 and 1999, even though both Figure 1 and Figure 2 suggest that the income gap widened. Because the housing problems included in our index are all relatively unusual, across-the board improvements almost inevitably imply larger absolute declines among the least affluent, because the more affluent are more likely to start off in problem-free housing. But the percentage decline in housing problems is also larger among low-income children. This result is more surprising, since the percentage increase in income is much greater for middle than low-income children.

Safety. Although low-income children's housing had fewer physical problems in 1989 than in 1973, Table 7 shows that the percentage of low-income parents who described crime as a serious problem in their neighborhood more than doubled during

decline in crowding in low-income children's homes between 1970 and 1973, after which the trend is the same in census and AHS data. 
these years. Concern about neighborhood crime increased far more among low-income parents than among more affluent parents.

But while low-income parents were more likely to believe that crime was a serious problem in their neighborhood, their beliefs do not seem to have been based on their own experiences. The National Crime Victimization Survey (NCVS) asks household members whether they have been victims of rape, robbery, burglary, and assault within the past six months. Table 8 compares responses in 1979-81 to responses in 1988-90. ${ }^{16}$ The first four columns cover everyone over the age of twelve. The last four columns are limited to individuals between the ages of twelve and twenty. The fraction of low-income households reporting a rape or robbery fell noticeably during the 1980s. There was no clear trend in assault. Thus while low-income parents clearly believed that their neighborhoods were more dangerous, it is not clear why they felt this way. Growing emphasis on violent crime in the nightly news may have been a factor.

Motor vehicles. Physical mobility is important to both children and adults. In America mobility depends to a great extent on motor vehicles, although this is somewhat less true in central cities than elsewhere. Table 9 shows trends in motor vehicle ownership by household income. These data come from the decennial census. ${ }^{17}$ The fraction of low-income children whose parents owned a car or truck did not change much during the 1970s, even though urbanization brought low-income parents closer to public transportation and the jump in gasoline prices made operating a vehicle more expensive. During the 1980s, the proportion of low-income children living in households with at least one motor vehicle rose slightly, and the proportion in households with two or more vehicles jumped by almost half, from 17.6 to 25.8 percent. The number of middleincome parents with two or more cars also jumped by almost half. These trends are hard to reconcile with the hypothesis that low-income children's households had less purchasing power in 1989 than in 1973. Indeed, they are hard to reconcile with the hypothesis implicit in Figure 2, namely that low-income households' purchasing power was flat during this period.

\footnotetext{
${ }^{16}$ The NCVS began in 1973, but we never managed to make the pre-1979 and post-1979 data consistent with one another.

${ }^{17}$ Micro-data from the 2000 Census were not yet available when we did this analysis.
} 
Air conditioning. Air conditioning is one of the few luxuries on which we have data. It was far from universal in 1973, even among the affluent, but it spread rapidly during the 1970s, 1980s, and 1990s. The fraction of households without air conditioning fell by roughly three-fifths between 1973 and 1999, and the proportionate decline was fairly uniform across the entire income distribution. One reason for this change was that the cost of air conditioners fell relative to most other goods and services.

Telephones. Table 9 shows data on telephone service from both the decennial census (1970 to 1990) and the AHS (1979 to 1999). ${ }^{18}$ The Census suggests that the proportion of low-income children in households without telephones fell by a third during the 1970s. The Census suggests that this trend was reversed in the 1980s, while the AHS suggests that it continued, but both agree that the change was small. During the 1990s the fraction of low-income children living in households without telephones fell dramatically, from 26 to 7 percent. Middle-income children's access to telephones also increased during the 1970s and 1990s. The absolute changes were smaller than among low-income children, but the percentage reduction in the chances of not having a home telephone was about the same for both groups (roughly four-fifths between 1970 and 1999).

Doctor Visits. Most pediatricians believe that children should have a medical checkup at least once a year, especially when they are young. The proportion of young children who have seen a doctor within the past year is therefore a widely used measure of whether parents are willing and able to ensure that their children get adequate medical attention. The National Health Interview Survey (NHIS) has collected data on doctor visits since the 1950s, but the NHIS questionnaire changed between 1980 and 1982, so changes during this interval may be methodological artifacts. The survey changed again in 1998, so we have no trend data after 1996.

Table 10 shows that the percentage of low-income children who had not visited a doctor within the past year declined sharply between 1970 and 1980. Both the absolute and proportional declines were greater among low-income children than among the more affluent. The same pattern recurs when we look at the total number of visits during the past year (data not shown). We suspect, but cannot prove, that this improvement was

\footnotetext{
${ }^{18}$ AHS data on telephone service is not available for 1973.
} 
partly attributable to broader Medicaid coverage, which made it easier for doctors and clinics to survive in poor neighborhoods. This change, in combination with urbanization, made medical care more physically as well as economically accessible in 1980 than in 1970.

Doctor visits continued to become more common among low-income children between 1982 and 1989, but the change was tiny, both in absolute terms and relative to changes among more affluent children. Low-income children's chances of seeing doctors improved more during the 1990s than during the 1980s, but not much more. The improvement among low-income children during the 1990s was, however, a contrast with the trend among more affluent children, whose chances of visiting a doctor declined slightly between 1989 and $1996 .^{19}$

Food Consumption. We do not have good data on changes in what children eat. The National Food Consumption Survey (NFCS), which asked homemakers what they served their families in 1955, 1965, and 1977, found that the diets of the poor and the affluent became more alike between 1965 and 1977 (Jencks and Mayer, 1987, Table 3.2). The NFCS was repeated in 1987, but the response rate was less than 40 percent, so we did not analyze the 1987 data.

Parents' reports of what they spent on food are also quite problematic. Few households keep detailed accounts, and many respondents round their estimates of

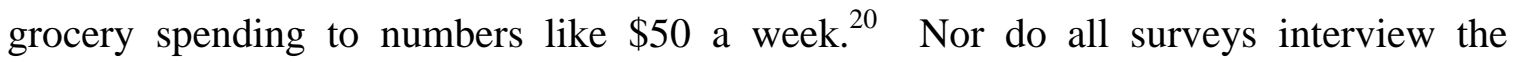
individual with primary responsibility for grocery shopping. Even when a survey does interview the primary shopper, she seldom knows how much other members of the household spend on food, especially if they consume it away from home. Survey

\footnotetext{
${ }^{19}$ Parents were somewhat more likely to say that their children had been sick enough to stay home from school or stay in bed in 1989 than in 1970. These reports are hard to interpret in light of the decline in mortality. Staying home from school or going to bed was not a strong predictor of children's doctor visits in any year, and the increase in visits was far larger than one would predict based on the increase in reported sickness (Mayer, 1991). Reports of chronic and acute conditions increased faster among lowincome than among middle-income children between 1970 and 1980 but the gap stayed constant during the 1980s (Pamuk et al. 1998). The increase in reports of ill-health could account for the rise in doctor visits among low-income children or the increase in reports of ill-health could be a byproduct of the increase in doctor visits.

${ }^{20}$ Rounding means that spending at a given percentile of the distribution, such as the median, can remain unchanged for long periods even though the distribution as a whole is shifting. Rounding can also introduce some random error in quintile means.
} 
estimates of poor households' grocery spending are also problematic because survey questions seldom include clear instructions about how respondents should treat food stamps. This problem was especially severe during the 1970s, when poor families had to make copayments for food stamps.

The quality of households' reports on food expenditure also appears to have deteriorated over time. When we compared the data collected from the Gallup Survey, the Consumer Expenditure Survey, and the Panel Study of Income Dynamics to the estimates of total food expenditure in the National Income and Product Accounts (NIPA), which are based on sales figures, the household surveys appeared to miss at least a quarter of total food consumption, and the ratio fell between the early 1970s and the early 1990s. Nonetheless, we present household data from two sources: the Panel Study of Income Dynamics (PSID) and the Consumer Expenditure Survey (CEX). Our measure of food expenditure is the sum of a family's reported expenditures at home and away from home.

The PSID began in 1968 and tracks households (including new households formed by members of the initial sample or their descendents) over time. It has asked about grocery spending in most years. ${ }^{21}$ The data for 1969 to 1971 differ from the data for later years, because the PSID asked respondents whether their estimate had included any money spent on alcohol or cigarettes, and if so, how much was spent on those items. The PSID subtracted these items to get a "pure" food measure. These questions were dropped in later years. The data for the 1970s are compromised by a series of changes in the treatment of food stamps. The only consistent time series, in our judgment, are the two that run from 1969 to 1971 and from 1981 to $1991 .{ }^{22}$

The US Department of Agriculture (USDA) has found that when large and small families spend the same amount per person (which they seldom do), the large families achieve higher levels of nutritional adequacy than the small families. Putting the same

\footnotetext{
${ }^{21}$ We omit years in which the PSID did not ask about food expenditure or in which we have no estimate for the value of food stamps. We also omit 1968, because the 1969 question was not repeated.

${ }^{22}$ A memo describing the many changes in the PSID questions since 1968 is available from the authors on request. We exclude the 1968 data, because there were major changes in the questionnaire between 1968 and 1969.
} 
point slightly differently we can say that there appear to be some economies of scale in food consumption, so that a couple with four children does not need to spend twice as much as a single parent with two children to achieve the same level of nutritional adequacy. Households have become smaller since 1969, so these economies of scale have diminished slightly. As a result, households need to spend slightly more per capita to attain the same level of dietary adequacy. To correct for this, we compare each family's total food spending to the US Department of Agriculture (USDA) “thrifty” food budget for a family of the relevant size. (This is also the budget used to calculate food stamp allotments.) The elasticity of the thrifty budget with respect to family size is 0.84 , which comes from an analysis of the expenditure levels required to ensure that households of different sizes purchase diets of equal nutritional value (Kerr and Peterkin, 1975). ${ }^{23}$

In 1991 the thrifty food budget for two adults, a teenager, and a ten year old was \$21.35 per person per month. NIPA data indicated that per capita food expenditures averaged $\$ 49.47$ per person per month, so the thrifty budget was a bit less than half the per capita mean. USDA adjusts the thrifty food budget for price changes using the BLS fixed-weight index for food consumed at home, which rose by an average of 6.0 percent a year between 1969 and 1991. Like any fixed-weight index, this one overstates the increase in expenditure required to buy food of constant palatability or nutritional adequacy, because it ignores the fact that consumers can substitute foods whose price has risen relatively slowly (such as chicken) for foods whose price has risen more rapidly (such as beef). To avoid (or at least minimize) this source of bias we adjust the 1991 thrifty budget using the NIPA chain-price index for food, which rose only 5.7 percent a year between 1969 and 1991.

Table 11 shows the ratio of PSID respondents' estimated monthly expenditure to the thrifty food budget for a household of the relevant size. The first two columns suggest that low-income children ate about ten percent better in 1971 than in 1969. There appears to be a sharp decline in low-income parents' food spending between 1971 and

\footnotetext{
${ }^{23}$ In the real world the observed elasticity of food expenditure with respect to family size is always less than 0.84 . We have not seen any evidence on whether children in larger families suffer adverse health effects as a result of this shortfall.
} 
1981, but this could be due to changes in the questionnaire. There was no change between 1981 and 1991. Food spending followed the same pattern for middle-income families, rising between 1969 and 1971, falling between 1971 and 1981, and changing little between 1981 and 1991. But the changes were less marked for middle than lowincome families.

To check our PSID results we also compared food expenditures in the 1972-73 Consumer Expenditure Survey (CEX) to expenditures in the 1989-90 CEX. Table 11 shows that in the CEX there is no clear trend in the ratio of food expenditure to need for low-income children. This finding reinforces our suspicion that the change in the PSID between 1971 and 1981 is attributable to changes in the questionnaire. Notice, too, that both the PSID and the CEX show that the ratio of food expenditure to need fell after 1971 among middle-income children. This decline is unlikely to reflect income constraints. It seems more likely to reflect underreporting.

After many years working with these data we have reluctantly concluded that there is no way of knowing whether the trends shown in Table 11 are real. We have included these results only because they constitute one of the few instances in which poor children's material standard of living does not appear to rise and suppressing results at odds with our basic thesis would be hard to defend.

\section{Conclusions}

The CPS suggests that children at all income levels gained ground during the 1990s. Our direct measures of material welfare tell the same story. Children at all income levels gained during the 1990s on almost every measure where improvement was possible. The principal exception was that middle and high-income children showed no increase in doctor visits during the 1990s.

The CPS presents a much gloomier picture of the 1970s and 1980s. In Figure 1 low-income children's real household income declines sharply between 1969 and 1989, while middle-income children's real income stagnates. Even in Figure 2 low-income children's real income stagnates during the 1970s and falls somewhat during 1980s, although middle-income children make significant progress. 
Direct measures of material welfare present a more optimistic picture than either Figure 1 or Figure 2. Income data suggest that low-income children's living standards should either decline or stagnate between 1969 and 1989. We do observe declines in home ownership and living in a single family dwelling. These changes are, however, linked to improvements in most measures of housing quality. Housing problems declined, and so did crowding. Air conditioning and telephones also became more common. Low-income parents felt that their neighborhoods were more crime-ridden, but the proportion who said they had been raped or robbed fell, while the proportion who said they had been assaulted remained constant. The proportion of low-income children in households that owned a motor vehicle was flat, but the proportion in households with two vehicles rose sharply. The percentage of low-income children who had seen a doctor within the past year rose. Food consumption remains a puzzle.

The story for middle-income children in the 1970s and 1980s is also full of ambiguities. Figure 1 suggests that middle-income children's real incomes stagnated during the 1970s and 1980s, while Figure 2 suggests a substantial increase. When we look at direct measures of the standard of living, we see many improvements during the 1970s but relatively few during the 1980s. Home ownership among middle-income parents rose slightly in the 1970s but declined significantly in the 1980s. Crowding declined in the 1970s and remained unchanged in the 1980s. Housing problems diminished in the 1970s but increased slightly in the 1980s. Air conditioning became more common in both decades, but telephone service rose more in the 1970s. Almost all middle-income parents had motor vehicles by 1970, but the fraction with two vehicles rose modestly in the 1970s and dramatically in the 1980s. Doctor visits for middle-income children increased at all ages in the 1970s but only for children over six in the 1980s. These results suggest that middle-income families' purchasing power rose more during the 1970s than during the 1980s, which is consistent with Figure 2 but not Figure 1.

Taken as a whole our findings suggest that Census statistics on household income were not a reliable guide to changes in the material standard of living during the last three decades of the twentieth century. Middle and low-income families made more progress during the 1970s and perhaps even the 1980s than Census reports implied. These inconsistencies can be reduced by using the CPI-U-RS rather than the CPI-U, as the 
Census Bureau now does when it publishes historical statistics on income. ${ }^{24}$ Inconsistencies between income statistics and direct measures of material well-being during the 1970s can also be reduced by using per capita household income instead of total household income, but the rationale for this change is weaker.

While income statistics and direct measures of material well-being moved up together during the 1990s, it would be rash to assume that this linkage will persist in the years ahead. Instead, the Census Bureau needs keep checking the validity of its data on changes in real income by establishing a parallel program to monitor trends in material well-being.

\footnotetext{
${ }^{24}$ The Bureau still uses the CPI-U to calculate historical trends in poverty, so these remain suspect (see Jencks, Mayer, and Swingle, 2002).
} 


\section{REFERENCES}

Boskin, Michael, Ellen Dulberger, Robert Gordon, Zvi Griliches, and Dale Jorgenson. 1996. Final Report of the Advisory Commission to Study the Consumer Price Index. Washington, Government Printing Office.

Council of Economic Advisers. 2002. Economic Report of the President. Washington, Government Printing Office.

Cutler, David, Mark McClellan, Joseph Newhouse, and Dahlia Remler. 1998. "Are Medical Prices Declining? Evidence for Heart Attack Treatments.” Quarterly Journal of Economics 113 (4): 991-1024.

Jencks, Christopher, and Susan E. Mayer. 1987. "Poverty and Material Hardship: How We Made Progress while Convincing Ourselves that We Were Losing Ground." Evanston, Northwestern University, Center for Urban Affairs and Poverty Research.

Jencks, Christopher, Susan E. Mayer, and Joseph Swingle. 2002. "Why Official Poverty Rates Provide No Useful Information about Changes in Children's Economic Welfare.” Cambridge, Malcolm Wiener Center for Social Policy, Harvard University.

Kerr, Richard and Betty Peterkin. 1975. "The Effect if Household Size on the Cost of Diets That are Nutritionally Equivalent." Washington, US Department of Agriculture, Consumer and Food Economics Institute, CFE (adm) 325.

Mayer, Susan E. 1991. "Are There Economic Barriers to Seeing the Doctor?" Chicago, University of Chicago, Harris School of Public Policy Studies, working paper.

Mayer, Susan E. and Christopher Jencks. 1989. "Poverty and the Distribution of Material Hardship." Journal of Human Resources 24: 88-114.

Michael, Robert, and Constance Citro, editors. 1995. Measuring Poverty: A New Approach. Washington, National Academy Press.

Pamuk, E., D. Makuk, K. Heck, C. Reuben, K. Lochner. 1998. "Socioeconomic Status and Health Chartbook," in Health, United States, 1988. Washington, Government Printing Office.

Schultze, Charles and Christopher Mackie, editors. 2002. At What Price? Conceptualizing and Measuring Cost-of-Living and Price Indexes. Washington, National Academy Press.

Stewart, Kenneth and Stephen Reed. 1999. "Consumer Price Index Research Series Using Current Methods: 1978-98." Monthly Labor Review (June): 29-38. 
US Bureau of the Census. 2000a. "Money Income in the United States: 1999." Current Population Reports, Washington, D.C., Government Printing Office.

US Bureau of the Census. 2000b. "Poverty in the United States: 1999." Current Population Reports, Washington, D.C., Government Printing Office. 
Figure 1: Percent Change since 1969 in the Pretax Income of

Children at the Tenth, Fiftieth, and Ninetieth Percentiles of

Total Household Income Using the CPI-U

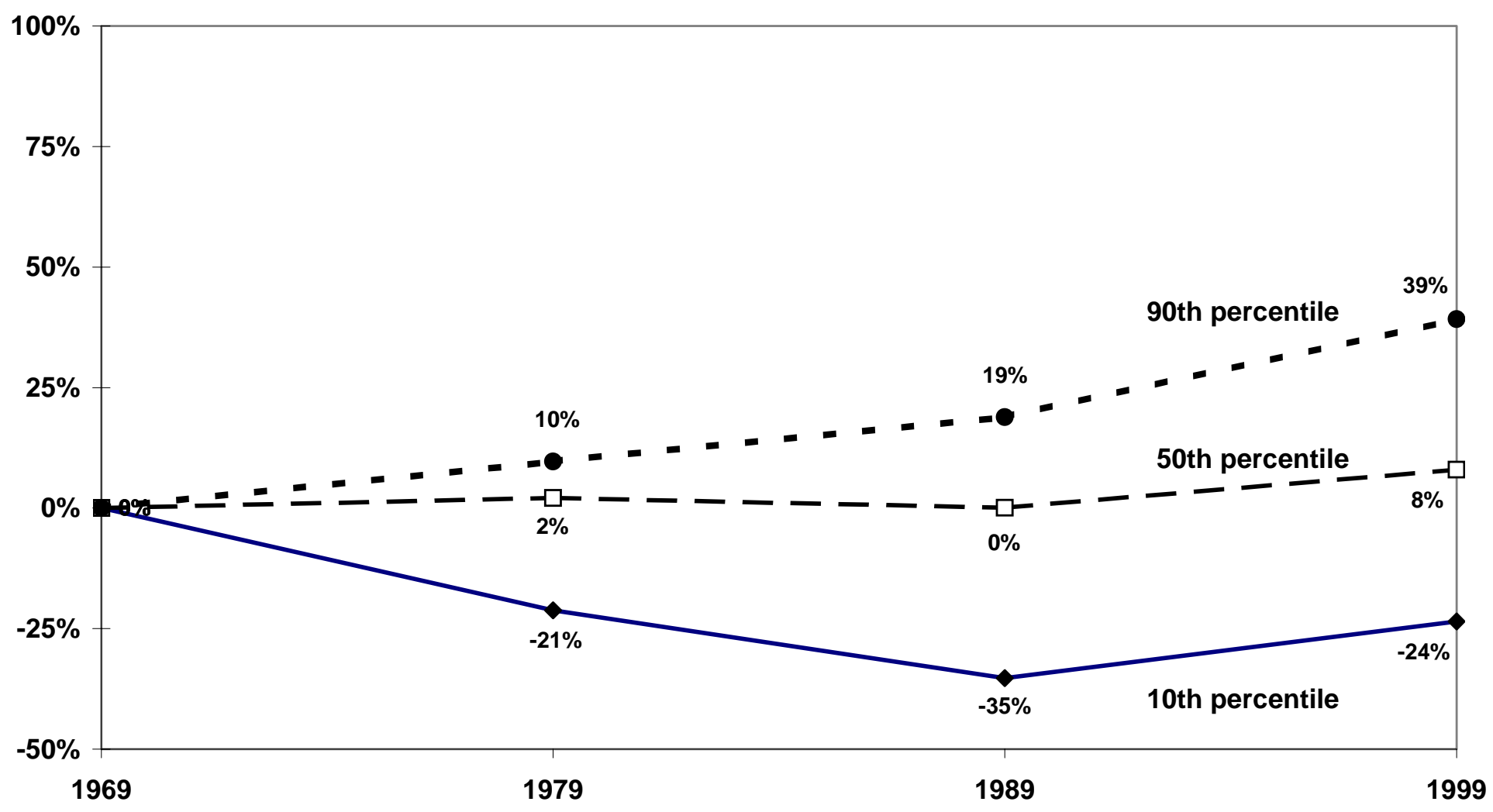

Source: Appendix Table A-2. 
Figure 2: Percent Change Since 1969 in the Pre-Tax Income of

Children at the Tenth, Fiftieth, and Ninetieth Percentiles of

Per Capita Household Income Using the CPI-U-RS

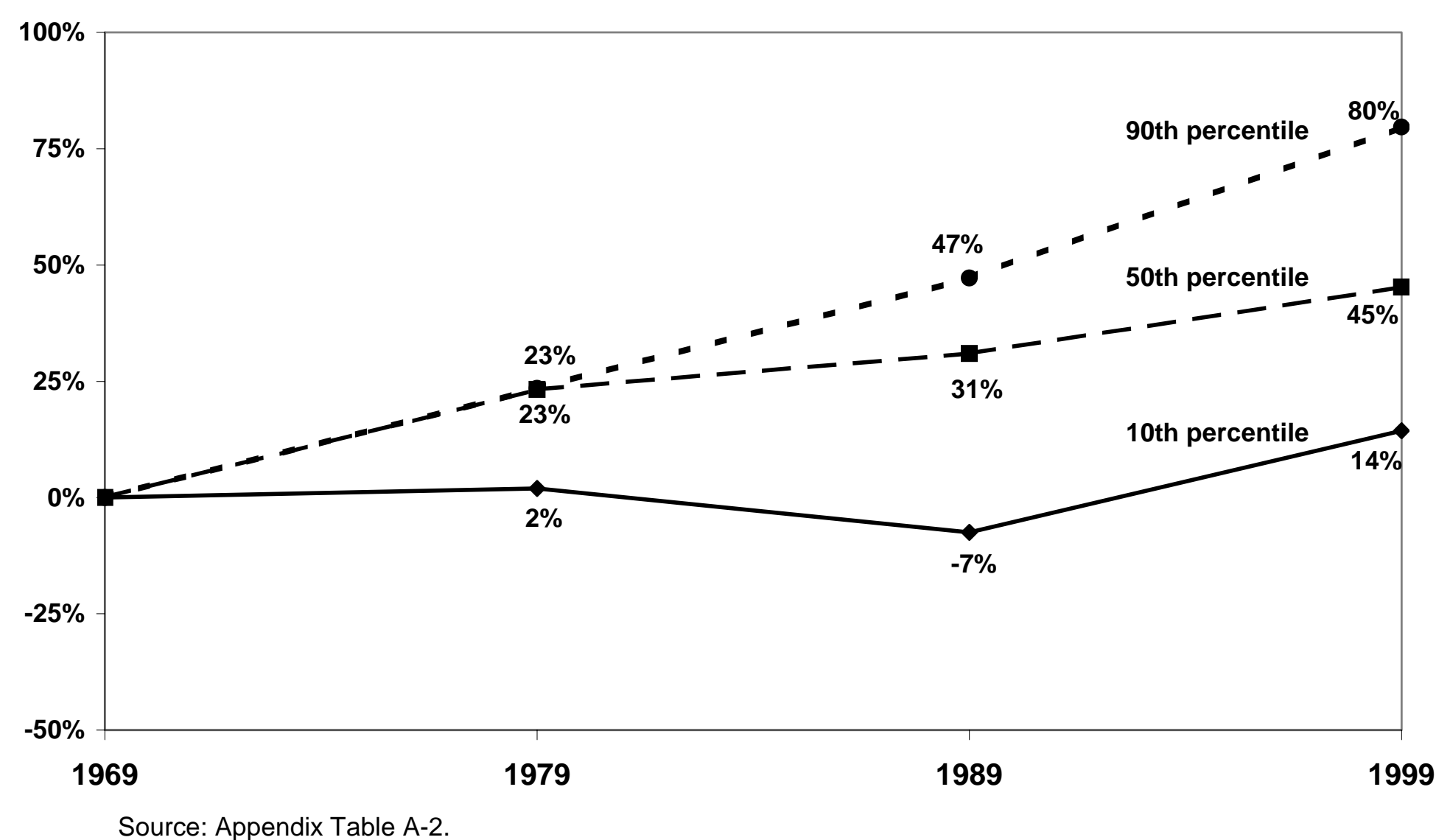

Source: Appendix Table A-2. 
Table 1: Percentage Increase in Three Widely Used

Government Price Indexes: 1969 to 1999

\begin{tabular}{|c|c|c|c|c|c|c|}
\hline \multirow[b]{2}{*}{ Price index (and source) } & \multicolumn{4}{|c|}{ Year } & \multicolumn{2}{|c|}{$\begin{array}{l}\text { Average annual } \\
\text { percent increase }\end{array}$} \\
\hline & 1969 & 1979 & 1989 & 1999 & $1969-99$ & $1989-99$ \\
\hline \multicolumn{7}{|l|}{ Overall } \\
\hline 1. CPI-U (BLS) & 100 & 198 & 338 & 454 & 5.17 & 3.00 \\
\hline 2. CPI-U-RS (BLS) & 100 & 187 & 308 & 401 & 4.74 & 2.69 \\
\hline 3. PCE chain-price index (NIPA) & 100 & 186 & 306 & 392 & 4.66 & 2.51 \\
\hline \multicolumn{7}{|l|}{ Excluding medical care } \\
\hline 4. CPI-U (BLS) & 100 & 197 & 331 & 438 & 5.05 & 2.84 \\
\hline 5. CPI-U-RS ${ }^{\mathrm{a}}$ & 100 & 187 & 301 & 387 & 4.61 & 2.54 \\
\hline 6. PCE chain price index ${ }^{\mathrm{b}}$ & $\mathrm{NA}$ & NA & 306 & 381 & NA & 2.22 \\
\hline
\end{tabular}

Note: All three indexes have been standardized to make the 1969 value 100.

a. Authors' approximation using (Line4/Line1)*Line2.

b. Based on comparing NIPA estimates of real and nominal growth in the value of personal after excluding medical care.

Sources: The CPI-U and PCE chain price data are from the Economic Report of the President, 2001.

The CPI-U-RS data are from US Bureau of the Census, Money Income in the United States, 1999. 
Table 2: Effect of Noncash Income and Taxes on Per Capita Resources of Children's Households, by Income Quintile and Year

(Incomes in 1999 CPI-U-RS Dollars)

\begin{tabular}{|c|c|c|c|c|c|c|c|}
\hline \multirow[b]{2}{*}{ Income concept and quintile } & \multicolumn{4}{|c|}{ Year } & \multicolumn{3}{|c|}{ Percent growth by decade } \\
\hline & 1969 & 1979 & 1989 & 1999 & $1970 \mathrm{~s}$ & $1980 \mathrm{~s}$ & 1990s \\
\hline \multicolumn{8}{|l|}{ Pre-tax money income per capita } \\
\hline Bottom quintile & $\$ 2,462$ & $\$ 2,544$ & $\$ 2,378$ & $\$ 2,830$ & 3.3 & -6.5 & 19.0 \\
\hline Middle quintile & 7,579 & 9,351 & 9,967 & 11,049 & 23.4 & 6.6 & 10.9 \\
\hline Top quintile & 17,620 & 21,309 & 25,909 & 33,790 & 20.9 & 21.6 & 30.4 \\
\hline Ratio of top to bottom quintile & 7.2 & 8.4 & 10.9 & 11.9 & & & \\
\hline \multicolumn{8}{|l|}{$\begin{array}{l}\text { After-tax money and nonmoney } \\
\text { income per capita }{ }^{\mathrm{a}}\end{array}$} \\
\hline Bottom quintile & $\mathrm{NA}^{\mathrm{b}}$ & 3,226 & 3,123 & 3,789 & NA & -3.2 & 21.3 \\
\hline Middle quintile & NA & 8,506 & 9,161 & 10,577 & NA & 7.7 & 15.5 \\
\hline Top quintile & NA & 17,121 & 21,079 & 27,936 & NA & 23.1 & 32.5 \\
\hline Ratio of top to bottom quintile & NA & 5.3 & 6.7 & 7.4 & & & \\
\hline
\end{tabular}

a. Census definition 14 .

Source: Tabulations from the March Current Population Survey. 
Table 3: Growth in Income, Consumption, and Population: 1969 to 1999 (All estimates are in 1999 dollars, using the PCE chain-price index)

\begin{tabular}{|c|c|c|c|c|c|c|c|}
\hline \multirow[b]{2}{*}{ Type of measure } & \multicolumn{4}{|c|}{ Year } & \multicolumn{3}{|c|}{ Percent growth by decade } \\
\hline & 1969 & 1979 & 1989 & 1999 & $1970 \mathrm{~s}$ & $1980 \mathrm{~s}$ & $1990 \mathrm{~s}$ \\
\hline \multicolumn{8}{|l|}{ Resources per capita in 1999 PCE dollars } \\
\hline Pretax money income (Census) & $\$ 11,689$ & $\$ 14,746$ & $\$ 17,628$ & $\$ 20,571$ & 26.2 & 19.5 & 16.7 \\
\hline Personal consumption expenditure (NIPA) & $\$ 11,696$ & $\$ 14,903$ & $\$ 18,599$ & $\$ 22,391$ & 27.4 & 24.8 & 20.4 \\
\hline Ratio (Row 2/Row 1) & 1.001 & 1.011 & 1.055 & 1.088 & 1.0 & 4.4 & 3.2 \\
\hline \multicolumn{8}{|l|}{ Population (in millions) } \\
\hline 7. Individuals ${ }^{a}$ & 202.7 & 225.1 & 247.4 & 279.1 & 11.0 & 9.9 & 12.8 \\
\hline 8. Households & 63.4 & 80.8 & 93.3 & 104.7 & 27.4 & 15.6 & 12.2 \\
\hline 9. Individuals/households ${ }^{\mathrm{b}}$ & 3.20 & 2.79 & 2.65 & 2.67 & -12.8 & -4.9 & 0.6 \\
\hline
\end{tabular}

a. Includes the institutional population and members of the armed forces living on bases and overseas.

b. Because the count of individuals includes those who did not live in households, the ratio of individuals to households exceeds the size of the average household.

Source: Consumption and population data and the PCE price index are from Economic Report of the President, 2001. Data on number of households and their mean income are from US Bureau of the Census, Money Income in the United States, 2000. 



\section{Table 4: Characteristics of Children's Housing, by Income Quintile, 1973 to 1999}

\begin{tabular}{lcccc}
\hline Measure & \multicolumn{3}{c}{ Quintile of Total Income } & \\
\cline { 2 - 4 } and year & Bottom & Middle & Top & All \\
\hline Percent in multi-family dwellings & & & & \\
1973 & 26.6 & 14.3 & 7.1 & 16.1 \\
1979 & 38.1 & 13.0 & 4.3 & 17.1 \\
1989 & 39.8 & 15.0 & 6.1 & 19.3 \\
1999 & 37.7 & 13.5 & 4.0 & 17.8 \\
Percentage point change & & & & \\
$1973-89$ & 13.2 & 0.7 & -1.0 & 3.2 \\
$1989-99$ & -2.1 & -1.5 & -2.1 & -1.5 \\
& & & & \\
Percent in rental units & & & & \\
1973 & 56.1 & 24.7 & 9.8 & 29.6 \\
1979 & 66.8 & 22.4 & 7.1 & 30.1 \\
1989 & 72.7 & 32.8 & 8.9 & 36.9 \\
1999 & 68.5 & 28.3 & 6.6 & 33.4 \\
Percentage point change & & & & \\
$1973-89$ & 16.6 & 8.1 & -0.9 & 7.3 \\
$1989-99$ & -4.2 & -4.5 & -2.3 & -3.5 \\
\hline
\end{tabular}

Levy Living Standards.xls, Tab 4, 4/18/02

Source: American Housing Survey. Unweighted cell sizes for each quintile are about 4,000 in 1973, 4,900 in 1979, 2,900 in 1989, and 3,400 in 1999. 
Table 5: Crowding in Children's Housing, by Income Quintile, 1973 to 1999

\begin{tabular}{|c|c|c|c|c|}
\hline \multirow{2}{*}{$\begin{array}{l}\text { Measure } \\
\text { and year }\end{array}$} & \multicolumn{3}{|c|}{ Quintile of Total Income } & \multirow[b]{2}{*}{ All } \\
\hline & Bottom & Middle & Top & \\
\hline \multicolumn{5}{|c|}{ Mean household size } \\
\hline 1973 & 5.2 & 5.0 & 5.3 & 5.1 \\
\hline 1979 & 4.5 & 4.7 & 5.0 & 4.7 \\
\hline 1989 & 4.5 & 4.6 & 4.7 & 4.6 \\
\hline 1999 & 4.2 & 4.5 & 4.6 & 4.5 \\
\hline \multicolumn{5}{|c|}{ Percentage point change } \\
\hline $1973-89$ & -0.7 & -0.4 & -0.6 & -0.5 \\
\hline 1989-99 & -0.3 & -0.1 & -0.1 & -0.1 \\
\hline \multicolumn{5}{|c|}{ Mean number of rooms } \\
\hline 1973 & 5.1 & 5.7 & 7.1 & 5.9 \\
\hline 1979 & 4.9 & 5.8 & 7.1 & 5.9 \\
\hline 1989 & 4.9 & 5.8 & 7.3 & 5.9 \\
\hline 1999 & 5.1 & 6.1 & 7.5 & 6.2 \\
\hline \multicolumn{5}{|c|}{ Percentage point change } \\
\hline 1973-89 & -0.2 & 0.1 & 0.2 & 0.0 \\
\hline 1989-99 & 0.2 & 0.3 & 0.2 & 0.3 \\
\hline \multicolumn{5}{|c|}{$\begin{array}{l}\text { Percent with more than } \\
\text { one person per room }\end{array}$} \\
\hline 1973 & 38.1 & 23.4 & 11.1 & 24.4 \\
\hline 1979 & 29.2 & 17.8 & 10.0 & 19.3 \\
\hline 1989 & 27.0 & 17.2 & 7.4 & 17.8 \\
\hline 1999 & 18.2 & 10.9 & 4.4 & 11.7 \\
\hline \multicolumn{5}{|c|}{ Percentage point change } \\
\hline $1973-89$ & -11.1 & -6.2 & -3.7 & -6.6 \\
\hline $1989-99$ & -8.8 & -6.3 & -3.0 & -6.1 \\
\hline
\end{tabular}
about 4,000 in 1973, 4,900 in 1979, 2,900 in 1989, and 3,400 in 1999. 
Table 6: Mean Number of Housing Problems Experienced by Children, by Income Quintile, 1973 to 1999

\begin{tabular}{lcccc}
\hline \multirow{2}{*}{ Year } & \multicolumn{3}{c}{ Quintile of Total Income } & \\
\cline { 2 - 4 } & Bottom & Middle & Top & All \\
\hline 1973 & .81 & .26 & .14 & .37 \\
1979 & .72 & .23 & .15 & .34 \\
1989 & .54 & .24 & .16 & .29 \\
1999 & .39 & .22 & .15 & .24 \\
Difference & & & & \\
$1973-89$ & -.26 & -.02 & .02 & -.08 \\
$1989-99$ & -.16 & -.02 & -.01 & -.05 \\
Percent change & & & & \\
$1973-89$ & $-33 \%$ & $-7 \%$ & $14 \%$ & $-21 \%$ \\
$1989-99$ & $-29 \%$ & $-8 \%$ & $-9 \%$ & $-18 \%$ \\
\hline
\end{tabular}

The seven problems included in this measure are holes in the floor, cracks or holes in the ceiling or walls, broken plaster or peeling paint, a leaky roof, not having a sewer or septic system, not having electric outlets in every room, and incomplete plumbing. See the text for details and Appendix Table A-2 for item by item data and for additional items not included in the index.

Source: American Housing Survey. Unweighted cell sizes for each quintile are about 4,000 in 1973, 4,900 in 1979, 2,900 in 1989, and 3,400 in 1999. 
Table 7: Percent of Children in Neighborhoods Where Parents Say Crime is a Serious Problem, by Income Quintile, 1973 to 1999

\begin{tabular}{crrrr}
\hline & \multicolumn{4}{c}{ Income Quintile } \\
\cline { 2 - 5 } Year & Bottom & Middle & Top & All \\
\hline 1973 & 14.3 & 13.5 & 13.8 & 13.6 \\
1979 & 24.8 & 18.7 & 17.0 & 19.7 \\
1989 & 31.9 & 23.1 & 17.7 & 24.2 \\
1999 & 23.0 & 14.5 & 9.3 & 15.6 \\
& & & & \\
Percentage point change & & & & \\
$1973-1989$ & 17.6 & 9.6 & 3.9 & 10.6 \\
$1989-1999$ & -8.9 & -8.6 & -8.4 & -8.6 \\
\hline
\end{tabular}

Source: American Housing Survey. 
Table 8: Victimization Rates per 100,000 by Age and Income Quintile, 1979-81 versus 1988-90.

\begin{tabular}{|c|c|c|c|c|c|c|c|c|}
\hline \multirow[b]{2}{*}{ Crime and Year } & \multicolumn{4}{|c|}{ All persons over the age of 12} & \multicolumn{4}{|c|}{$\begin{array}{c}\text { Persons between the } \\
\text { ages of } 12 \text { and } 20\end{array}$} \\
\hline & $\begin{array}{l}\text { Bottom } \\
\text { quintile }\end{array}$ & $\begin{array}{l}\text { Middle } \\
\text { quintile }\end{array}$ & $\begin{array}{c}\text { Top } \\
\text { quintile }\end{array}$ & All & $\begin{array}{l}\text { Bottom } \\
\text { quintile }\end{array}$ & $\begin{array}{l}\text { Middle } \\
\text { quintile }\end{array}$ & $\begin{array}{c}\text { Top } \\
\text { quintile }\end{array}$ & All \\
\hline \multicolumn{9}{|l|}{ Rape } \\
\hline $1979-81$ & 205 & 82 & 58 & 104 & 467 & 163 & 117 & 228 \\
\hline $1988-90$ & 137 & 62 & 24 & 64 & 268 & 118 & 87 & 167 \\
\hline Percent change & -33.2 & -24.4 & -58.6 & 38.5 & -42.6 & -27.6 & -25.6 & -26.8 \\
\hline \multicolumn{9}{|l|}{ Robbery } \\
\hline $1979-81$ & 1140 & 600 & 464 & 672 & 1779 & 1095 & 844 & 1107 \\
\hline $1988-90$ & 978 & 383 & 325 & 520 & 1498 & 625 & 725 & 968 \\
\hline Percent change & -14.2 & -36.2 & -30.0 & -22.6 & -15.8 & -42.9 & -14.1 & -12.6 \\
\hline \multicolumn{9}{|l|}{$\begin{array}{l}\text { Aggravated } \\
\text { assault }\end{array}$} \\
\hline $1979-81$ & 1323 & 998 & 775 & 997 & 2896 & 1770 & 1504 & 1887 \\
\hline $1988-90$ & 1262 & 779 & 560 & 823 & 2743 & 1894 & 1363 & 1933 \\
\hline Percent change & -4.6 & -21.0 & -27.7 & -17.5 & -5.3 & 7.0 & -9.4 & 2.4 \\
\hline \multicolumn{9}{|l|}{ Simple assault } \\
\hline $1979-81$ & 2096 & 1703 & 1620 & 1748 & 4251 & 3094 & 3236 & 3300 \\
\hline $1988-90$ & 2153 & 1552 & 1186 & 1534 & 4587 & 3803 & 3352 & 3722 \\
\hline Percent change & 2.7 & -8.9 & -26.8 & -12.2 & 7.9 & 22.9 & 3.6 & 12.8 \\
\hline
\end{tabular}

Source: National Criminal Victimization Survey (tabulations by David Knutson). Unweighted cell sizes for robbery and aggravated assault are at least 20,000. Cell sizes for rape are roughly half as large. 
Table 9: Percent of Children in Households with Motor Vehicles, Air Conditioners, and Telephones, by Income Quintile, 1973-1999

\begin{tabular}{|c|c|c|c|c|}
\hline \multirow[b]{2}{*}{ Measure and year } & \multicolumn{4}{|c|}{ Income Quintile } \\
\hline & Bottom & Middle & Top & All \\
\hline \multicolumn{5}{|c|}{ At least one motor vehicle } \\
\hline 1970 & 68.1 & 95.6 & 98.8 & 90.1 \\
\hline 1980 & 68.4 & 95.7 & 98.4 & 90.0 \\
\hline 1990 & 69.7 & 97.0 & 99.0 & 91.1 \\
\hline \multicolumn{5}{|c|}{ Percentage point change: } \\
\hline $1970-1990$ & 1.6 & 1.4 & 0.2 & 1.0 \\
\hline \multicolumn{5}{|c|}{ Two or more motor vehicles } \\
\hline 1970 & 16.6 & 44.4 & 74.8 & 45.1 \\
\hline 1980 & 17.6 & 50.7 & 76.6 & 49.0 \\
\hline 1990 & 25.8 & 75.3 & 92.9 & 67.4 \\
\hline \multicolumn{5}{|c|}{ Percentage point change: } \\
\hline $1970-1990$ & 9.2 & 30.9 & 18.1 & 22.3 \\
\hline \multicolumn{5}{|l|}{ Air conditioning } \\
\hline 1973 & 30.5 & 48.0 & 62.0 & 46.8 \\
\hline 1979 & 33.0 & 54.7 & 65.0 & 51.7 \\
\hline 1989 & 48.2 & 67.3 & 75.7 & 65.2 \\
\hline 1999 & 69.2 & 78.4 & 84.5 & 78.2 \\
\hline \multicolumn{5}{|c|}{ Percentage point change: } \\
\hline $1973-1989$ & 17.7 & 19.3 & 13.7 & 18.4 \\
\hline 1989-1999 & 21.0 & 11.1 & 8.8 & 13.0 \\
\hline \multicolumn{5}{|l|}{ Telephone service } \\
\hline \multicolumn{5}{|l|}{ Census } \\
\hline 1970 & 63.9 & 91.7 & 98.5 & 86.4 \\
\hline 1980 & 76.2 & 95.8 & 99.0 & 91.6 \\
\hline 1990 & 74.2 & 96.5 & 99.5 & 91.9 \\
\hline \multicolumn{5}{|l|}{ AHS } \\
\hline 1979 & 72.7 & 94.7 & 98.4 & 89.8 \\
\hline 1989 & 74.0 & 95.7 & 98.6 & 91.2 \\
\hline 1999 & 93.0 & 98.2 & 98.4 & 97.0 \\
\hline \multicolumn{5}{|c|}{ Percentage point change: } \\
\hline Census: 1970-1980 & 12.3 & 4.1 & .5 & 5.2 \\
\hline Census: 1980-1990 & -2.0 & .7 & .5 & .3 \\
\hline AHS: $\quad 1979-1989$ & 1.3 & 1.0 & .2 & 1.4 \\
\hline AHS: $\quad 1989-1999$ & 19.0 & 2.5 & -.2 & 5.8 \\
\hline
\end{tabular}

Sources: Decennial Census and American Housing Survey. 
Table 10. Percent of Children Who Had Not Visited a Doctor in the Past Year, by Income Quintile: 1970 to 1996

\begin{tabular}{|c|c|c|c|}
\hline \multirow[b]{2}{*}{ Year and child's age } & \multicolumn{3}{|c|}{ Income quintile } \\
\hline & Bottom & Middle & Top \\
\hline \multicolumn{4}{|l|}{1970 to 1980} \\
\hline \multicolumn{4}{|l|}{ Children under seven } \\
\hline 1970 & 26.5 & 15.9 & 9.4 \\
\hline 1980 & 11.9 & 10.2 & 7.2 \\
\hline Percentage point change & -14.6 & -5.7 & -2.2 \\
\hline Ratio of 1980 to 1970 & .45 & .64 & .77 \\
\hline \multicolumn{4}{|c|}{ Children aged seven to seventeen } \\
\hline 1970 & 45.1 & 36.9 & 25.7 \\
\hline 1980 & 32.7 & 30.8 & 26.0 \\
\hline Percentage point change & -12.4 & -6.1 & .3 \\
\hline Ratio of 1980 to 1970 & .73 & .83 & 1.01 \\
\hline \multicolumn{4}{|l|}{1982 to 1989} \\
\hline \multicolumn{4}{|l|}{ Children under seven } \\
\hline 1982 & 14.4 & 11.8 & 8.4 \\
\hline 1989 & 14.0 & 10.9 & 5.6 \\
\hline Percentage point change & -.4 & -.9 & -2.8 \\
\hline Ratio of 1989 to 1982 & .97 & .92 & .67 \\
\hline \multicolumn{4}{|c|}{ Children aged seven to seventeen } \\
\hline 1982 & 32.6 & 32.3 & 23.0 \\
\hline 1989 & 31.4 & 27.3 & 17.5 \\
\hline Percentage point change & -1.2 & -5.0 & -5.5 \\
\hline Ratio of 1989 to 1982 & .96 & .85 & .76 \\
\hline \multicolumn{4}{|l|}{1989 to 1996} \\
\hline \multicolumn{4}{|l|}{ Children under seven } \\
\hline 1989 & 14.0 & 10.9 & 5.6 \\
\hline 1996 & 12.7 & 10.9 & 6.8 \\
\hline Percentage point change & -1.3 & 0 & 1.2 \\
\hline Ratio of 1996 to 1989 & .91 & 1.00 & 1.21 \\
\hline \multicolumn{4}{|c|}{ Children aged seven to seventeen } \\
\hline 1989 & 31.4 & 27.3 & 17.5 \\
\hline 1996 & 29.0 & 27.9 & 18.0 \\
\hline Percentage point change & -2.4 & .6 & .5 \\
\hline Ratio of 1996 to 1989 & .92 & 1.02 & 1.03 \\
\hline
\end{tabular}

Source: National Health Interview Survey (tabulations by David Knutson). Cell sizes for bottom deciles range from 1,000 to 1,400 for children under seven and from 1,600 to 2,500 for children aged 7-17. 
Table 11. Food Expenditures in Children's Households as a

Proportion of the 1992 Thrifty Food Budget, by Quintile of Total Income in the PSID

\begin{tabular}{lcccrrr}
\hline Income or con- & \multicolumn{2}{c}{ PSID-I } & \multicolumn{2}{c}{ PSID-II } & \multicolumn{2}{c}{ CEX } \\
\cline { 2 - 7 } sumption quintile $^{\mathrm{a}}$ & 1969 & 1971 & 1981 & 1991 & $1972-73$ & $1989-90$ \\
\hline \multirow{2}{*}{ Bottom } & .94 & 1.04 & .87 & .86 & .87 & .87 \\
Middle & 1.13 & 1.16 & 1.11 & 1.08 & 1.36 & 1.29 \\
Top & 1.53 & 1.53 & 1.52 & 1.50 & 2.03 & 2.05 \\
All & 1.17 & 1.20 & 1.15 & 1.12 & 1.39 & 1.36 \\
$\begin{array}{l}\text { Ratio of reported } \\
\text { food expenditure } \\
\text { per capita to NIPA }\end{array}$ & .754 & .761 & .756 & .734 & .711 & .656 \\
\hline
\end{tabular}

Source: Tabulations by Tim Veenstra, Judith Levine, and Scott Winship.

a. PSID households are allocated to income quintiles on the basis of their mean income for the year in which food expenditures were reported and the previous calendar year. CEX expenditures are allocated to quintiles on the basis of their total consumption during the same twelve months for which they reported their food expenditures. CEX expenditures are reported quarterly. PSID expenditures are reported annually. The thrifty food budget was adjusted for inflation using the NIPA chain-price index for food, not the CPI index that USDA uses for food stamps. 
Appendix Table A-1

Total and Per Capita Household Income of Children under Eighteen By Quintile, Using Different Income Measures: 1969 to 1999

\begin{tabular}{|c|c|c|c|c|c|c|c|c|}
\hline \multirow[b]{2}{*}{$\begin{array}{l}\text { Price index, income } \\
\text { measure, and year }\end{array}$} & \multicolumn{3}{|c|}{ Total household income } & \multicolumn{4}{|c|}{$\underline{\text { Per capita household incom }}$} & \multirow{2}{*}{$\begin{array}{c}\text { Price } \\
\text { index } \\
(1999=100)\end{array}$} \\
\hline & $\begin{array}{l}\text { Bottom } \\
\text { Quintile }\end{array}$ & $\begin{array}{l}\text { Middle } \\
\text { Quintile }\end{array}$ & $\begin{array}{c}\text { Top } \\
\text { Quintile }\end{array}$ & & $\begin{array}{c}\text { Bottom } \\
\text { Quintile }\end{array}$ & $\begin{array}{l}\text { Middle } \\
\text { Quintile }\end{array}$ & $\begin{array}{c}\text { Top } \\
\text { Quintile }\end{array}$ & \\
\hline \multicolumn{9}{|l|}{ Pretax money income } \\
\hline \multicolumn{9}{|l|}{ CPI-U } \\
\hline 1969 & 15,788 & 44,129 & 94,195 & & 2,787 & 8,580 & 19,947 & 22.0 \\
\hline 1979 & 12,704 & 45,122 & 98,691 & & 2,728 & 10,030 & 22,856 & 43.6 \\
\hline 1989 & 10,871 & 44,349 & 109,147 & & 2,451 & 10,270 & 26,696 & 74.4 \\
\hline 1999 & 12,342 & 48,074 & 138,911 & & 2,830 & 11,049 & 33,790 & 100 \\
\hline \multicolumn{9}{|l|}{ CPI-U-RS } \\
\hline 1969 & 13,947 & 38,982 & 83,209 & & 2,462 & 7,579 & 17,620 & 24.9 \\
\hline 1979 & 11,844 & 42,067 & 92,010 & & 2,544 & 9,351 & 21,309 & 46.7 \\
\hline 1989 & 10,550 & 43,041 & 105,928 & & 2,378 & 9,967 & 25,909 & 76.7 \\
\hline 1999 & 12,342 & 48,074 & 138,911 & & 2,830 & 11,049 & 33,790 & 100 \\
\hline \multicolumn{9}{|l|}{ Ratio of 1999 to 1969} \\
\hline CPI-U & 0.78 & 1.09 & 1.47 & & 1.02 & 1.29 & 1.69 & 4.54 \\
\hline CPI-U-RS & 0.88 & 1.23 & 1.67 & & 1.15 & 1.46 & 1.92 & 4.01 \\
\hline \multicolumn{9}{|c|}{$\begin{array}{l}\text { After-tax money and } \\
\text { non-money income (Defn 14) }\end{array}$} \\
\hline \multicolumn{9}{|l|}{ CPI-U } \\
\hline 1979 & 15,916 & 41,042 & 79,761 & & 3,461 & 9,124 & 18,360 & 43.6 \\
\hline 1989 & 14,215 & 40,916 & 89,122 & & 3,218 & 9,440 & 21,718 & 74.4 \\
\hline 1999 & 16,561 & 45,956 & 115,387 & & 3,789 & 10,577 & 27,936 & 100 \\
\hline \multicolumn{9}{|l|}{ CPI-U-RS } \\
\hline 1979 & 14,839 & 38,263 & 74,362 & & 3,226 & 8,506 & 17,117 & 46.7 \\
\hline 1989 & 13,795 & 39,710 & 86,493 & & 3,123 & 9,161 & 21,078 & 76.7 \\
\hline 1999 & 16,561 & 45,956 & 115,387 & & 3,789 & 10,577 & 27,936 & 100 \\
\hline \multicolumn{9}{|l|}{$\begin{array}{l}\text { Ratio of } 1999 \text { to } 1979 \\
\text { income using CPI-U-RS }\end{array}$} \\
\hline Pre-tax money income & 1.04 & 1.14 & 1.51 & \# & 1.11 & 1.18 & 1.59 & 2.14 \\
\hline $\begin{array}{l}\text { After-tax money and } \\
\text { non-money income }\end{array}$ & 1.12 & 1.20 & 1.55 & \# & 1.17 & 1.24 & 1.63 & 2.14 \\
\hline
\end{tabular}

Source: March Current Population Survey, tabulations by Joseph Swingle. Households are weighted by the number of children under eighteen. The CPI-U-RS is from US Bureau of the Census (2000a). The CPI-U is from Council of Economic Advisers (2000). $\quad$ Levy Living Standards.xls, Tab A-1, 4/18/02 
Appendix Table A.2: Children's Housing Problems by Income Quintile, 1973-1999

\begin{tabular}{lcccc}
\hline $\begin{array}{l}\text { Measure } \\
\text { and year }\end{array}$ & \multicolumn{3}{c}{ Quintile of Total Income } & \\
\cline { 2 - 3 } Incomplete Plumbing & Bottom & Middle & Top & All \\
\hline 1973 & 10.8 & 0.9 & 0.2 & 3.0 \\
1979 & 5.6 & 1.2 & 0.3 & 2.0 \\
1989 & 3.7 & 1.9 & 1.8 & 2.2 \\
1999 & 2.4 & 1.1 & 0.5 & 1.2 \\
& & & & \\
No sewer or septic system & & & & \\
1973 & 7.3 & 0.6 & 0.0 & 2.0 \\
1979 & 3.4 & 0.6 & 0.1 & 1.1 \\
1989 & 1.1 & 0.0 & 0.0 & 0.3 \\
1999 & 0.4 & 0.0 & 0.0 & 0.1
\end{tabular}

No electrical outlet in one or more rooms

$\begin{array}{lcccc}1973 & 14.0 & 4.5 & 2.3 & 6.3 \\ 1979 & 7.8 & 3.1 & 1.8 & 4.0 \\ 1989 & 5.2 & 2.5 & 1.1 & 2.8 \\ 1999 & 3.2 & 1.7 & 1.5 & 2.1\end{array}$

Holes in floor

$\begin{array}{lllll}1973 & 6.8 & 1.3 & 0.5 & 2.6 \\ 1979 & 6.9 & 1.5 & 0.6 & 2.8 \\ 1989 & 4.7 & 1.1 & 0.6 & 1.8 \\ 1999 & 4.5 & 1.0 & 0.7 & 1.7\end{array}$

Cracks or holes in walls or ceiling

$\begin{array}{lllll}1973 & 16.3 & 5.7 & 2.6 & 7.9 \\ 1979 & 17.7 & 4.5 & 3.0 & 7.9 \\ 1989 & 16.3 & 5.7 & 2.9 & 7.8 \\ 1999 & 13.5 & 7.0 & 3.6 & 7.9\end{array}$

Broken plaster or peeling paint (more than 1 sq. ft.)

\begin{tabular}{lcccc}
1973 & 10.1 & 5.4 & 2.7 & 6.0 \\
1979 & 15.8 & 5.1 & 3.7 & 7.7 \\
1989 & 12.2 & 4.6 & 2.4 & 6.0 \\
1999 & 6.7 & 3.9 & 1.6 & 3.8 \\
\hline
\end{tabular}


Appendix Table A.2 (continued)

\begin{tabular}{|c|c|c|c|c|}
\hline \multirow{2}{*}{$\begin{array}{l}\text { Measure } \\
\text { and year }\end{array}$} & \multicolumn{3}{|c|}{ Quintile of Total Income } & \multirow[b]{2}{*}{ All } \\
\hline & Bottom & Middle & Top & \\
\hline \multicolumn{5}{|c|}{ Leaky roof } \\
\hline 1973 & 15.4 & 7.5 & 5.7 & 9.2 \\
\hline 1979 & 14.6 & 7.4 & 5.3 & 8.9 \\
\hline 1989 & 11.2 & 8.3 & 7.2 & 8.5 \\
\hline 1999 & 8.0 & 7.6 & 6.6 & 7.4 \\
\hline \multicolumn{5}{|c|}{ No air conditioning } \\
\hline 1973 & 69.5 & 52.0 & 38.0 & 53.2 \\
\hline 1979 & 67.0 & 45.3 & 35.0 & 48.3 \\
\hline 1989 & 51.8 & 32.7 & 24.3 & 34.8 \\
\hline 1999 & 30.8 & 21.6 & 15.5 & 21.8 \\
\hline \multicolumn{5}{|c|}{ Mean age of housing unit } \\
\hline 1973 & 28.1 & 24.3 & 20.0 & 24.1 \\
\hline 1979 & 29.8 & 24.6 & 20.1 & 24.7 \\
\hline 1989 & 29.5 & 26.1 & 21.8 & 26.1 \\
\hline 1999 & 33.4 & 30.8 & 24.2 & 29.4 \\
\hline \multicolumn{5}{|c|}{ Housing unit built before 1940} \\
\hline 1973 & 40.2 & 31.7 & 22.3 & 31.3 \\
\hline 1979 & 38.0 & 27.3 & 18.1 & 27.6 \\
\hline 1989 & 25.9 & 20.1 & 14.8 & 20.8 \\
\hline 1999 & 23.8 & 20.8 & 12.5 & 18.6 \\
\hline \multicolumn{5}{|c|}{ Rats or mice } \\
\hline 1973 & 23.1 & 11.6 & 8.1 & 13.8 \\
\hline 1979 & 25.1 & 14.2 & 11.7 & 15.9 \\
\hline \multicolumn{5}{|l|}{ Rats } \\
\hline 1989 & 14.0 & 4.8 & 2.0 & 6.2 \\
\hline 1999 & 2.5 & 0.8 & 0.7 & 1.3 \\
\hline
\end{tabular}

